\title{
Characterization of Fragaria virginiana and $F$. chiloensis in a Minimal-chill, Winter Annual Production System
}

\author{
Colleen Kennedy, Tomas N. Hasing, and Vance M. Whitaker ${ }^{1}$ \\ 672, Wimauma, FL 33598 \\ Additional index words. flowering, mortality, runnering, supercore
}

Gulf Coast Research and Education Center, University of Florida, 14625 CR

\begin{abstract}
Wild Fragaria supercore accessions from the U.S. Department of Agriculture (USDA) National Plant Germplasm System collection have been evaluated in temperate climates; however, there have been no characterizations of supercore accessions in nontemperate climates or in annualized production systems. Because Florida can serve as a model system for annualized winter and spring production worldwide, the objective of this study was to characterize an elite group of wild strawberry accessions under field and high tunnel production systems for mortality and the phenological responses of flowering and runner production. The wild accessions along with cultivars were planted in openfield and high tunnel production environments in a randomized complete block design within each environment with raised beds serving as blocks. Four replications of fiveplant plots were planted in each of two environments in 2 separate years. With the exception of Darrow 72, F. chiloensis accessions did not perform well in the minimumchill annualized winter production system. The accessions of this species generally did not flower and were prolific instead in runner production. The $F$. virginiana accessions performed better with $F$. virginiana subsps. grayana and virginiana accessions appearing more adapted for minimum-chill winter production because they flowered well and had few runners. We conclude that NC 96-48-1 (PI 612324), NC 95-21-1 (PI 612569), Darrow 72 (PI 236579), and RH 30 (PI 612499) would be attractive for inclusion in germplasm development in a minimal-chill, winter annual production system. In addition to producing many flowers and few runners, these accessions had low mortality.
\end{abstract}

The modern cultivated strawberry, $F$. xananassa, is fully interfertile with its wild octoploid progenitor species $F$. virginiana and $F$. chiloensis. Thus, these species are in the primary germplasm pool for breeding purposes and are a repository of novel traits. A collection of 38 elite wild genotypes (Hancock et al., 2002) is housed at the National Clonal Germplasm Repository in Corvallis, OR. This collection, known as the Fragaria supercore, is a subset of a larger collection and represents the genetic diversity of the collection as a whole with a minimum of redundancy. The accessions within the collection, denoted by PI numbers, include $F$. chiloensis from North and South America that initiate flowers under short days (SD) and are male, female, or hermaphrodite and $F$. virginiana from North America that are both SD and remontant (RM) flowering and are also male, female, or hermaphrodite (Table 1).

Received for publication 3 Feb. 2014. Accepted for publication 1 May 2014.

Partial funding for this project was provided under a USDA-ARS Specific Cooperative Agreement via the Small Fruits Crop Germplasm Committee.

We acknowledge Dr. Kim Hummer and staff at the USDA-ARS National Clonal Germplasm Respository for their provision of propagules of the Fragaria supercore collection.

${ }^{1}$ To whom reprint requests should be addressed; e-mailvwhitaker@ufl.edu.
Since the cultivated strawberry resulted from an accidental hybridization of these two wild species in Europe $\approx 250$ years ago (Hancock, 1999), attempts have been made to reconstruct the cultivated species using wild $F$. virginiana and $F$. chiloensis (Hancock et al., 2010; Luby et al., 2008; Stegmeir et al., 2010). Previously, $F$. virginiana glauca was crossed with $F$. ×ananassa for incorporating RM flowering (Bringhurst, 1976; Dale et al., 2002; Hancock et al., 2002), and F. chiloensis was used to improve fruit size of SD cultivars for California (Bringhurst and Voth, 1984). Since then, other important traits such as drought and salinity tolerance, red stele resistance, strawberry aphid resistance, and winterhardiness have been introgressed from wild sources (Barritt and Shanks, 1980; Daubeny, 1990; Galletta et al., 1989). Today breeders are using wild accessions of strawberry to improve early yields, achieve disease resistance, and enhance fruit quality attributes (Ludwig et al., 2013) such as flavor and aroma (Finn et al., 2013).

A single-year multistate comparison of supercore accessions was conducted in five states in northern temperate latitudes. Data were collected on survival, cold tolerance, disease susceptibility, runner production, flowering and fruiting dates, and fruit size and quality in Maryland, Michigan, Minnesota, Oregon, and Pennsylvania (Hancock et al., 2001). Several accessions performed well overall environments including CA 1499 (PI 551735) for large early fruit and NC 95-19-1 (PI 612486), Frederick 9 (PI 612493), and RH 30 (PI 612499 ) for vigor and good fruit color.

Accessions of the Fragaria supercore have been evaluated in temperate climates; however, supercore accessions have not been characterized in non-temperate climates or in annualized production systems. The annualized winter and spring strawberry production system used in Florida, California, and central Mexico provide most of the U.S. supply of fresh strawberries. Additionally, this approach to production is used around the world in the Mediterranean, Australia, and many other regions. Environmental conditions in spring/summer perennial production systems in northern latitudes are vastly different from these locales. In addition to the often humid conditions and dramatic temperature fluctuations in the subtropical Florida growing region, soils in central Florida are very low in organic matter and consist mainly of Myakka fine sand (USDA, NRCS, National Soil Survey Center, 2013). Thus, Florida is an extreme environment that can serve as an excellent testing ground for other winter and spring production regions of the world.

In strawberry, the emergence and development of leaves, crowns, roots, runners, and inflorescences are influenced by temperature, light intensity, and light quality (Hancock, 1999). The most common environmental change used by plants to control seasonal behavior is photoperiod or daylength (Summerfield, 1999). Plants with RM flowering respond to a combination of daylength and temperature and can be quantitative long day (LD), qualitative LD, or truly day-neutral. SD plants initiate flower buds in the shortening days of summer and fall, winter, or early spring when days are short and temperatures are warm enough; however, high temperatures can inhibit bud formation in SD and RM plants as reviewed in Stewart and Folta (2010).

In North American strawberry nursery production, two transplant types are typically used: bareroot and plug transplants. Plug plants are produced mainly in North Carolina and Canada for the Florida industry by rooting small runner plants in late summer in plug trays, and bareroot transplants are field propagated in the same regions and fresh dug in the fall. Both types of plants are established in October, and fruit harvest begins in late November and continues through March. Exposure to the combination of cooler temperatures and shortening days of September in the nurseries initiates flower buds in the transplant crowns before planting in the winter production fields. Stolon development usually occurs during the long days of summer when temperatures are warm. However, plants in the winter fruiting field continue to produce runners during the beginning of the fruiting season, although the amount of runnering differs among cultivars. Because early marketable yield is negatively affected by runner production (Albregts and Howard, 1986), runners are removed. Therefore, runnering in the fruiting field is considered an undesirable trait. 
Table 1. Name, PI number, taxon code, Fragaria accession number from the National Clonal Germplasm Repository, Corvallis, OR (CFRA), origin, flowering type, and gender of accessions of the Fragaria supercore and three Florida cultivars.

\begin{tabular}{|c|c|c|c|c|c|c|}
\hline$\overline{\text { Genotype }}$ & PI no. & Taxon code ${ }^{z}$ & CFRA no. & Origin & Flowering $^{\mathrm{y}}$ & Gender ${ }^{x}$ \\
\hline Darrow 72 & 236579 & FCPC & 24.001 & Chile & $\mathrm{SD}$ & $\mathrm{H}$ \\
\hline RCP 37 & 551445 & FCL & 34.002 & No. California & SD & M \\
\hline WLSP-08 & 551453 & FCL & 42.001 & Washington & SD & $\mathrm{F}$ \\
\hline Ice H59 & 551471 & FVP & 58.002 & California & $\mathrm{RM}$ & $\mathrm{H}$ \\
\hline Pacific Crest Trail 110 & 551527 & FVC & 110.001 & Oregon & $\mathrm{RM}$ & $\mathrm{M}, \mathrm{F}, \mathrm{H}$ \\
\hline CA 1367 & 551728 & FCL & 357.002 & Central California & SD & $\mathrm{H}$ \\
\hline Termas de Chillan & 552091 & FCPC & 796.001 & Chile & SD & $\mathrm{H}$ \\
\hline Rio Palena & 602568 & FCPC & 1100.002 & Chile & SD & $\mathrm{H}$ \\
\hline March Brava & 612316 & FCPC & 1088.001 & Chile & SD & $\mathrm{H}$ \\
\hline La Tapera & 612317 & FCPC & 1092.002 & Chile & SD & $\mathrm{F}$ \\
\hline NAH 3 & 612318 & $\mathrm{FCC}$ & 1480.001 & Ecuador & SD & $\mathrm{H}$ \\
\hline JP 95-9-6 & 612320 & FVGY & 1455.001 & Georgia & SD & $\mathrm{H}$ \\
\hline NC 96-35-2 & 612323 & FVVS & 1557.001 & Alabama & SD & $\mathrm{F}$ \\
\hline NC 96-48-1 & 612324 & FVVS & 1580.001 & So. Carolina & SD & $\mathrm{F}$ \\
\hline NC 96-5-3 & 612325 & FVVS & 1620.001 & No. Carolina & SD & $\mathrm{H}$ \\
\hline BC Canada & 612488 & FCP & 1690.001 & British Columbia & $\mathrm{SD}$ & $\mathrm{H}$ \\
\hline Scotts Creek & 612490 & FCP & 1692.001 & Central California & SD & $\mathrm{F}$ \\
\hline Eagle 14 & 612492 & FVVN & 1694.001 & Ontario & $\mathrm{RM}$ & $\mathrm{H}$ \\
\hline Fredrick 9 & 612493 & FVVN & 1695.001 & Ontario & RM & $\mathrm{M}, \mathrm{F}$ \\
\hline Black Hills S. Dak. & 612494 & FVG & 1696.001 & So. Dakota & $\mathrm{RM}$ & $\mathrm{F}$ \\
\hline LH 50-4 & 612495 & FVVN & 1697.001 & Montana & $\mathrm{RM}$ & $\mathrm{H}$ \\
\hline Montreal River 10 & 612497 & FVVN & 1699.001 & Ontario & RM & $\mathrm{M}, \mathrm{H}$ \\
\hline RH 23 & 612498 & FVVN & 1700.001 & Minnesota & $\mathrm{RM}$ & $\mathrm{H}$ \\
\hline RH 30 & 612499 & FVVN & 1701.001 & Minnesota & RM & $\mathrm{H}$ \\
\hline LH 30-4 & 612501 & FVG & 1703.001 & Montana & $\mathrm{RM}$ & $\mathrm{H}$ \\
\hline NC 95-21-1 & 612569 & FVGY & 1414.001 & Mississippi & SD & $\mathrm{F}$ \\
\hline Florida Elyana & & FA & & Florida & SD & $\mathrm{H}$ \\
\hline Florida Festival & & FA & & Florida & SD & $\mathrm{H}$ \\
\hline Florida Radiance & & FA & & Florida & $\mathrm{SD}$ & $\mathrm{H}$ \\
\hline
\end{tabular}

${ }^{\text {zSee Table } 2 .}$

yPer Hancock et al., 2001, 2010; RM = remontant; SD = short-day.

xPer Hancock et al., 2001, 2010; $\mathrm{M}=$ male; $\mathrm{F}=$ female; $\mathrm{H}=$ hermaphrodite.

The temperatures during the Florida production season can fluctuate dramatically. During planting season in October, the average high/low is $29 / 18^{\circ} \mathrm{C}$. In December, when strawberries are in full production, the average high/low is $23 / 11^{\circ} \mathrm{C}$. Temperatures fall to $22 / 10{ }^{\circ} \mathrm{C}$ during the coldest month, January, and rise to $26 / 13^{\circ} \mathrm{C}$ at peak production in March. However, there are usually several nights with frost each season, and overhead irrigation is used to protect plants from freeze damage. Protective systems such as high tunnels are becoming more popular worldwide for season extension/optimization as well as for frost protection (Hancock and Simpson, 1995; Ogden and van Iersel, 2009; Salame-Donoso et al., 2010). Temperature difference in high tunnels compared with the open field affects flowering and other physiological responses. Donoso et al. (2009) found that plant diameter and total yield were higher in the high tunnel compared with the open field.

In addition to temperatures during the production season, temperatures during transplant development are also important in strawberry. In an annual system, Durner et al. (1987) reported early yield differences in SD genotypes in response to differing levels of chilling in a North Carolina nursery. They found that with 'Chandler', slight chilling (less than $125 \mathrm{~h}$ ) suppressed early yield and that increased chilling (greater than $125 \mathrm{~h}$ ) enhanced early yield; on the other hand, chilling in 'Tufts' decreased early yields. Flowering in the temperate environment is strongly influenced by temperature and each cultivar has its own photoperiod $\times$ temperature interaction response curve with a minimum number of floral induction cycles required (whether SDs or low temperature) (Heide et al., 2013). In the University of Florida strawberry breeding program, plug plants of advanced selections are propagated over the summer in local greenhouses and do not receive any chilling before planting. This is done to select for cultivars that have very low or nonexistent chilling requirements for proper plant development and early flowering. Evaluation under these same conditions would allow similar observations of these important accessions.

For wild germplasm to be usefully characterized, the material should be evaluated in multiple and diverse environments and production systems. Because Florida can serve as a model system for annualized winter and spring production worldwide, the objective of this study was to characterize an elite group of wild strawberry accessions (Hancock et al., 2001) and commercial cultivars under field and high tunnel production systems for mortality and the phenological responses of flowering and runner production.

\section{Materials and Methods}

Plant material and data collection. Experiments were performed in the field and under a high tunnel at the University of Florida Gulf Coast Research and Education Center (GCREC) in Balm, FL, during the
2010-11 and 2012-13 seasons. Twenty-six accessions of the Fragaria supercore collection were obtained from the USDA-ARS National Clonal Germplasm Repository in Corvallis, OR. The accessions were propagated from runner tips that were rooted under intermittent mist in a greenhouse at the GCREC. Rooted tips were transplanted into soilless media (Fafard 2 Mix; Fafard, Agawam, MA) in 3.8-L pots to make mother plants for further propagation. Mother plants of three University of Florida cultivars, Florida Elyana, Florida Radiance (internationally known as Florida Fortuna), and Strawberry Festival (internationally known as Florida Festival), were also maintained in $3.8-\mathrm{L}$ pots on the same greenhouse benches for propagation. After 3 months, runner tips were collected from mother plants on 7 Sept. 2010 and 17 Sept. 2012 and rooted under intermittent mist in plug trays (Landmark Plastic Corporation, Akron, OH). In 2010-11, 60-cell trays were used and in 2012-13 40-cell trays were used. In both years, the plug transplants were grown for $\approx 6$ weeks in a common greenhouse environment before planting in the field. According to standard practice in the breeding program, pests were chemically or biologically controlled as needed and per label recommendations on both the mother plants and the plug plants.

Raised beds in the field were formed 4 to 6 weeks before planting and were $71 \mathrm{~cm}$ wide at the base, $61 \mathrm{~cm}$ wide on the top, and $25 \mathrm{~cm}$ high. In 2010-11, the beds were not fumigated, and in 2012-13, the beds were fumigated with a mixture of 1,3D-dichloropropene and chloropicrin before planting according to current commercial standards and covered in black high-density polyethylene mulch. Two rows of planting holes were punched per bed with $38-\mathrm{cm}$ in-row spacing. The wild accessions and cultivars were planted in open-field and high tunnel production environments and were arranged in a randomized complete block design within each environment with raised beds serving as blocks. Four replications of five-plant plots were planted in each of two environments on 22 Oct. 2010 and on 25 Oct. 2012. After establishment, plants were irrigated through the drip tape twice per day with one irrigation between $0800 \mathrm{HR}$ and $0900 \mathrm{HR}$ and another between $1300 \mathrm{HR}$ and $1400 \mathrm{HR}$ with durations of between $30 \mathrm{~min}$ and $60 \mathrm{~min}$ depending on time of year and age of the plants. Fertigation was applied through drip tape beginning $10 \mathrm{~d}$ after transplanting. Fertilization and pest control followed current crop recommendations for strawberry in Florida (Santos et al., 2011); however, no products were applied to control powdery mildew resulting from concurrent research (Kennedy et al., 2013)

Data on the number of flowers, number of runners, and mortality were collected in the open field and high tunnel. In both years, the number of flowers was counted on a whole plot basis and then flowers per plant were calculated based on the total number of flowers divided by plants per plot. When flowering became heavy (more than 100 
flowers/plant), flowers were counted on only one representative plant per plot. In 2010-11, the flowers were counted monthly from 3 Dec. 2010 through 14 Mar. 2011 and weekly in April. In 2010-11, the flowers were not removed after counting. In 2012-13, the flowers were counted bimonthly from 15 Nov. 2012 through 28 Feb. 2013 and flowers were removed after counting. In both years, runners were counted on a whole plot basis and runners per plant were calculated as previously described. In 2010-11, runner counting was conducted monthly from 1 Jan. 2011 through 23 Mar. 2011 and in 2012-13, runners were counted weekly from 15 Nov. 2012 through 28 Mar. 2013. The runners were removed after counting. The number of flowers and runners per plant were summed by month. Mortality was recorded at the time of runner counting. All genotypes (Table 1) were assigned a taxon code per Pinkerton and Finn (2005) and the Germplasm Resources Information Network (USDA, ARS, National Genetic Resources Program, 2014) for ease of identifying subspecies (Table 2).

Weather data were collected from the Florida Automated Weather Network (Fig. 1) (Florida Automated Weather Network, 2014). The weather station used is located at the GCREC adjacent to the research field.

Table 2. Subspecies names and taxon codes for Fragaria virginiana and $F$. chiloensis.

\begin{tabular}{ll}
\hline Subspecies & $\begin{array}{c}\text { Taxon } \\
\text { code }^{z}\end{array}$ \\
\hline $\begin{array}{l}\text { Fragaria chiloensis } \\
\text { subsp. f. chiloensis }\end{array}$ & FCC \\
$\begin{array}{l}\text { F. chiloensis } \text { f. patagonica } \\
\quad \text { subsp. } \text { chiloensis }\end{array}$ & FCPC \\
$\begin{array}{l}\text { F. chiloensis subsp. lucida } \\
\text { F. chiloensis subsp. pacifica }\end{array}$ & FCL \\
F. virginiana subsp. glauca & FCP \\
F. virginiana subsp. grayana & FVG \\
F. virginiana subsp. platypetala & FVGY \\
F. virginiana subsp. virginiana (North) & FVP \\
F. virginiana subsp. virginiana (South) & FVVS \\
F. cascadensis & FVC \\
\hline
\end{tabular}

${ }^{\mathrm{z}}$ According to Pinkerton and Finn (2005) and the Germplasm Resources Information Network (GRIN) (USDA, ARS, National Genetic Resources Program, 2014).
Statistical analysis. Mortality area under the curve (AUC) was calculated for each genotype, and a Type III test of fixed effects was performed using the GLIMMIX procedure of $\mathrm{SAS}^{\circledR}$ software (Version 9.3; SAS Institute Inc., Cary, NC) and means were separated with Fisher's protected least significant difference test at a $P \leq 0.05$. Flower and runner data for the total season were analyzed by means of generalized linear mixed models with a Poisson distribution conditional on the random effects of the blocks (only random effect in the models). For the runner data, the model included the fixed effects of species, year, location, and their interactions. The accession's least square means (LS-means) were separated within each environment and year. For the flower data, the years were analyzed separately because of the different counting methods (removing and not removing flowers); therefore, the year effect and its interactions were omitted from each model. The accessions LS-means were separated within each environment. The statistical analysis was performed using the GLIMMIX procedure of SAS ${ }^{\circledR}$ software (Version 9.3; SAS Institute Inc.).

\section{Results and Discussion}

Mortality. Mortality, as measured by AUC, exhibited significant genotype $\times$ year effects; however, the triple interaction of genotype $x$ year $\times$ production environment was not significant (Table 3 ). Therefore, data for mortality are presented by year with environments (open field and high tunnel) combined (Table 4). Examining species and subspecies groupings, in $2010-11$, the $F$. chiloensis subspecies did not differ in mortality except for one of the $F$. chiloensis $f$. patagonica subsp. chiloensis accessions, La Tapera (PI 612317). In 2010 11, La Tapera had significantly higher mortality than other members of the $F$. chiloensis f. patagonica subsp. chiloensis group and had the overall highest mortality (22.9 AUC). Among the $F$. virginiana species in 2010-11, only $F$. virginiana subsp. platypetala showed a significantly higher mortality of 23.1 AUC than other members of this group. This subspecies contains only one accession, Ice H59
(PI 551471). Pacific Crest Trail 110 (PI 551527) was previously classified within the platypetala subspecies; however, it was recently reclassified in the new species, $F$. cascadensis (Hummer, 2012). Fragaria cascadensis also had significantly higher mortality (22.5 and 1.4 AUC in 2010-11 and 2012-13, respectively) than some other groups.

In 2012-13, variation for mortality was greater among $F$. chiloensis than among $F$. virginiana accessions. Within $F$. chiloensis, there were no subspecies trends for high mortality; however, F. chiloensisf. patagonica subsp. chiloensis as a group had a significantly lower mortality with ranges from 2.4 to 0.0 AUC compared with other members of this group. All the accessions within $F$. virginiana subsp. virginiana had low mortality with overall means ranging from 2.3 to 0.0 AUC with no significant differences.

In 2010-11, there was significantly higher average mortality (4.7 AUC) than in 2012-13 (1.6). Several accessions differed widely between years. For example, CA 1367 (PI 551728), Temas de Chillan (PI 552091), and Rio Palena (PI 602568) ranged from 7.8 to 9.6 AUC mortality in $2010-11$ and 0.0 in 2012-13. This reaction may be attributed to the fact that no soil fumigants were applied in 2010-11. However, Scotts Creek (PI 612490), NAH 3 (PI 612318), and RCP 37 (PI 551445) were the opposite with higher mortalities in 2012-13 compared with 2010-11.

Several accessions exhibited no mortality in either year. These include the $F$. chiloensis accessions Darrow 72 (PI 236579), BC Canada (PI 612488), and WLSP-08 (PI 551453) and the $F$. virginiana accessions NC 96-35-2 (PI 612323), LH 50-4 (PI 612495), and RH 30 (PI 612499) (Table 4).

A sample of $F$. chiloensis $f$. patagonica subsp. chiloensis accession La Tapera (PI 612317) was submitted to the Plant Disease Diagnostic Clinic at GCREC on 12 Apr. 2011 for diagnosis and Gnomonia (species inconclusive) was isolated from the crowns. The symptoms of flagging, wilt, and general decline on this genotype were typical across all accessions that did not survive in both years.

Flower production. The interaction of genotype $\times$ environment was significant in

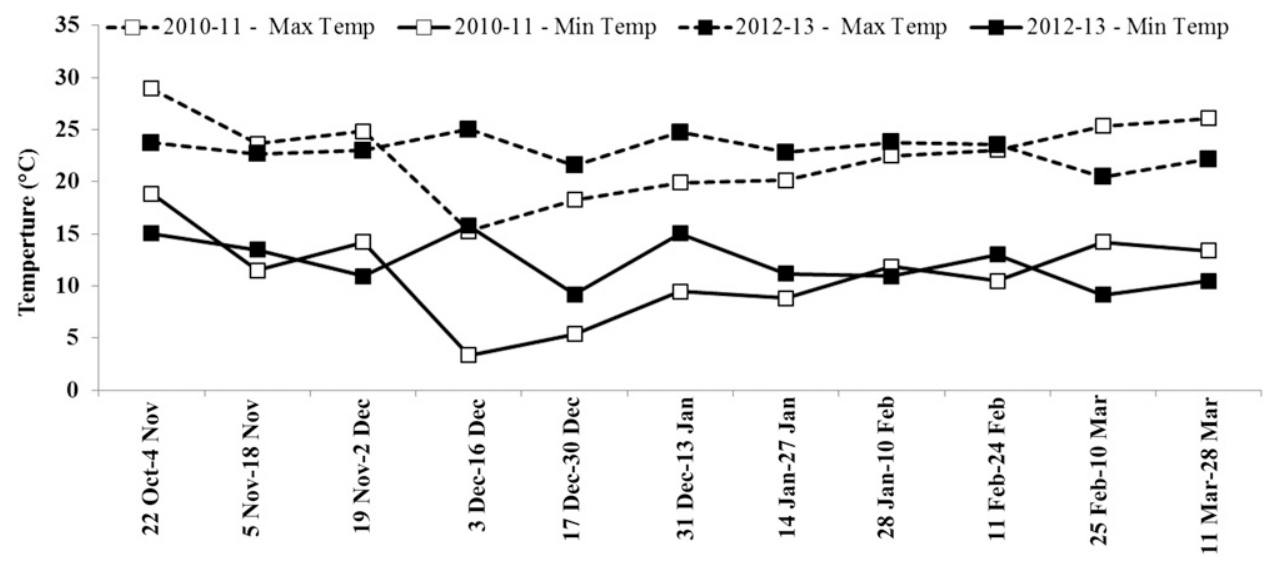

Fig. 1. Two-week average minimum and maximum air temperature for the strawberry growing season in Balm, FL, in 2010-11 and 2012-13. 
both production years (Table 5); therefore, separate analyses are reported for each environment (Fig. 2). Little to no flower production was observed for all the $F$. chiloensis accessions in both years and environments (0.2 to 1.0 flowers/plant) with the exception ered profusely in all years and environments (34.5 to 67.6 flowers/plant) compared with the other F. chiloensis accessions. The difference in flowering is likely the result of variation for chill requirement with Darrow 72 evidently requiring no chilling to initiate flowers under SD conditions.

All $F$. virginiana accessions flowered in both years and in both environments to some degree with wide variability among subspecies of Darrow 72 (PI 236579). Darrow 72 flow-

and accessions within subspecies. In 2012-13, flowering began in December with the exception of Black Hills S. Dak (PI 612494) and JP 95-9-6 (PI 612320), which began flowering in January and February, respectively. In Beltsville, MD, all the comparable accessions began flowering within $9 \mathrm{~d}$ of each other. In 2010-11, onset of flowering was widely variable with some accessions beginning in November and others as late March.

Overall $F$. virginiana subsp. virginiana had the highest number of flowers per plant over the season with the northern subgrouping producing an average of 44.0 and 33.3 flowers/plant in the field and high tunnel in 2010-11. In 2012-13, there were 102.5 flowers/plant in the field and 123.0 in the

Table 3. Type III tests for fixed effects for mortality area under the curve of wild strawberry (Fragaria sp.) accessions and commercial cultivars in Balm, FL, in 2010-11 and 2012-13 in high tunnel and openfield environments.

\begin{tabular}{lccrr}
\hline Source of variation & Numerator df & Denominator df & F value & Pr $>$ F \\
\hline Year $(Y)$ & 1 & 12 & 10.37 & 0.0073 \\
Genotype $(\mathrm{G})$ & 28 & 336 & 3.49 & $<0.0001$ \\
Environment (E) & 1 & 12 & 0.02 & 0.8952 \\
$\mathrm{Y} \times \mathrm{E}$ & 1 & 12 & 0.00 & 0.9876 \\
$\mathrm{G} \times \mathrm{E}$ & 28 & 336 & 1.29 & 0.1507 \\
$\mathrm{Y} \times \mathrm{G}$ & 28 & 336 & 3.66 & $<0.0001$ \\
$\mathrm{Y} \times \mathrm{E} \times \mathrm{G}$ & 28 & 336 & 1.30 & 0.1435 \\
\hline
\end{tabular}

Table 4. Mortality area under the curve of wild strawberry (Fragaria sp.) accessions and commercial cultivars in Balm, FL, in 2010-11 and 2012-13 seasons, sorted by overall mean (not shown).

\begin{tabular}{|c|c|c|c|c|}
\hline Genotype & PI no. & Taxon code & $2010-11$ & $2012-13$ \\
\hline La Tapera & 612317 & FCPC & $22.85 \mathrm{a}^{\mathrm{z}}$ & $2.44 \mathrm{~cd}$ \\
\hline Pacific Crest Trail 110 & 551527 & FVC & $22.46 \mathrm{a}$ & $1.38 \mathrm{~cd}$ \\
\hline Ice H59 & 551471 & FVP & $23.10 \mathrm{a}$ & $0.28 \mathrm{~d}$ \\
\hline NAH 3 & 612318 & FCC & $3.53 \mathrm{~b}$ & $11.99 \mathrm{a}$ \\
\hline Florida Elyana & & FA & $9.63 \mathrm{~b}$ & $3.96 \mathrm{~cd}$ \\
\hline Scotts Creek & 612490 & FCP & $0.00 \mathrm{~b}$ & $9.91 \mathrm{ab}$ \\
\hline Florida Festival & & FA & $5.94 \mathrm{~b}$ & $3.70 \mathrm{~cd}$ \\
\hline CA 1367 & 551728 & FCL & $9.63 \mathrm{~b}$ & $0.00 \mathrm{~d}$ \\
\hline Termas de Chillan & 552091 & FCPC & $8.15 b$ & $0.00 \mathrm{~d}$ \\
\hline Rio Palena & 602568 & FCPC & $7.78 \mathrm{~b}$ & $0.00 \mathrm{~d}$ \\
\hline RCP 37 & 551445 & FCL & $0.00 \mathrm{~b}$ & $5.27 \mathrm{bc}$ \\
\hline Florida Radiance & & FA & $4.81 \mathrm{~b}$ & $0.34 \mathrm{~cd}$ \\
\hline March Brava & 612316 & FCPC & $4.75 \mathrm{~b}$ & $0.20 \mathrm{~d}$ \\
\hline NC 96-5-3 & 612325 & FVVS & $3.85 \mathrm{~b}$ & $0.00 \mathrm{~d}$ \\
\hline LH 30-4 & 612501 & FVG & $2.41 \mathrm{~b}$ & $0.00 \mathrm{~d}$ \\
\hline Eagle 14 & 612492 & FVVN & $2.38 \mathrm{~b}$ & $0.00 \mathrm{~d}$ \\
\hline RH 23 & 612498 & FVVN & $0.00 \mathrm{~b}$ & $2.34 \mathrm{~cd}$ \\
\hline NC 96-48-1 & 612324 & FVVS & $1.93 \mathrm{~b}$ & $0.00 \mathrm{~d}$ \\
\hline Fredrick 9 & 612493 & FVVN & $1.93 \mathrm{~b}$ & $0.00 \mathrm{~d}$ \\
\hline Black Hills S. Dak. & 612494 & $\mathrm{FVG}$ & $1.93 \mathrm{~b}$ & $0.00 \mathrm{~d}$ \\
\hline JP 95-9-6 & 612320 & FVGY & $0.00 \mathrm{~b}$ & $1.83 \mathrm{~cd}$ \\
\hline Montreal River 10 & 612497 & FVVN & $0.00 \mathrm{~b}$ & $1.04 \mathrm{~cd}$ \\
\hline NC 95-21-1 & 612569 & FVGY & $0.00 \mathrm{~b}$ & $1.04 \mathrm{~cd}$ \\
\hline Darrow 72 & 236579 & FCPC & $0.00 \mathrm{~b}$ & $0.00 \mathrm{~d}$ \\
\hline BC Canada & 612488 & FCP & $0.00 \mathrm{~b}$ & $0.00 \mathrm{~d}$ \\
\hline WLSP-08 & 551453 & FCL & $0.00 \mathrm{~b}$ & $0.00 \mathrm{~d}$ \\
\hline NC 96-35-2 & 612323 & FVVS & $0.00 \mathrm{~b}$ & $0.00 \mathrm{~d}$ \\
\hline LH 50-4 & 612495 & FVVN & $0.00 \mathrm{~b}$ & $0.00 \mathrm{~d}$ \\
\hline RH 30 & 612499 & FVVN & $0.00 \mathrm{~b}$ & $0.00 \mathrm{~d}$ \\
\hline
\end{tabular}

${ }^{\mathrm{z}}$ Genotype means followed by the same letter within column are not significantly different at $P \leq 0.05$.

Table 5. Type III test of fixed effects of genotype and environment on flower production of wild strawberry (Fragaria sp.) species accessions and commercial cultivars in Balm, FL, in 2010-11 and 2012-13.

\begin{tabular}{|c|c|c|c|c|c|c|}
\hline \multirow[b]{2}{*}{ Effect } & \multirow[b]{2}{*}{ Numerator df } & \multirow[b]{2}{*}{ Denominator df } & \multicolumn{2}{|c|}{$2010-11$} & \multicolumn{2}{|c|}{$2012-13$} \\
\hline & & & F value & $\operatorname{Pr}>F$ & $\bar{F}$ value & $\operatorname{Pr}>F$ \\
\hline Environment (E) & 1 & 6 & 1.33 & 0.2933 & 0.19 & 0.6816 \\
\hline Genotype (G) & 28 & 168 & 63.50 & $<0.0001$ & 160.33 & $<0.0001$ \\
\hline $\mathrm{G} \times \mathrm{E}$ & 28 & 168 & 3.68 & $<0.0001$ & 10.23 & $<0.0001$ \\
\hline
\end{tabular}

high tunnel. The southern group produced an average of 50.8 and 50.7 in the field and high tunnel in 2010-11 and 90.7 in the field and 82.0 in the high tunnel in 2012-13. There was, however, great variability in individual accessions within the northern grouping. For example, Montreal River 10 (PI 612497) produced 17.6 flowers/plant in the field and 18.1 in the high tunnel in 2010-11 and 44.9 flowers/plant in the field and 57.3 in the high tunnel in 2012-13, whereas LH 50-4 (PI 612495 ) had an average of 41.5 flowers/plant in the field and 33.4 in the high tunnel in 2010-11 and 173.7 flowers/plant in the field and 232.6 in the high tunnel 2012-13. LH50-4 had considerably more flowers than 'Radiance' that had 14.0 in the field and 21.4 in the high tunnel in 2010-11 and 125.6 in the field and 107.8 in the high tunnel in 2012-13. Lower flower numbers are expected for commercial cultivars that produce very large fruits, many larger than $40 \mathrm{~g}$, whereas fruit size was uniformly small for all the wild accessions (less than $5 \mathrm{~g}$ ).

Overall flowers/plant in the high tunnel were nearly equal to those in the field (Fig. 2). The northern grouping of $F$. virginiana subsps. virginiana and platyepetala tended to have more flowers/plant in the tunnel, whereas the subsps. virginiana (South), glauca, and grayana had more flowers/plant in the field. Overall, F. cascadensis had fewer flowers in the high tunnel compared with the field. Although flowering in the field and high tunnel were similar early in the season (November and December) of both years, flowering in the high tunnel was reduced later in the season. This effect was most pronounced in 2012-13 where in December there were 5.8 and 7.8 flowers/plant in the field and high tunnel, respectively, and in January, there were 36.9 and 5.3 flowers/plant in the field and high tunnel, respectively. This may be a response to less chilling in the high tunnel or to higher temperatures, which may have inhibited floral production.

In both years, total flower production for each accession behaved the same in the field as in the high tunnel with the exception of $\mathrm{RH}$ 23 (PI 612498) and RH 30 (612499) in 2010 11 and Pacific Crest Trail 110 in 2012-13. In 2010-11, RH 30 produced statistically more flowers than RH 23 in the high tunnel, and, although not statistically different, $\mathrm{RH} 30$ produced fewer flowers than RH 23 in the field. This exception did not occur in 2012 13. Also of note are SD accessions NC 95-21-1 (PI 612569) originating from Mississippi and JP 95-9-6 (PI 612320) from Georgia. These two accessions had a greater number of flowers in 2010-11, which was the colder of the 2 years. It could be that the higher temperatures in 2012-13 arrested flower development or did not provide inductive conditions for genotypes requiring more chilling.

Overall, flower production in the early season was generally higher in the high tunnel compared with the field and some accessions flowered in the tunnel before flowering in the field (Fig. 2). In 2010-11, both accessions of $F$. virginiana subsp. glauca flowered in the 


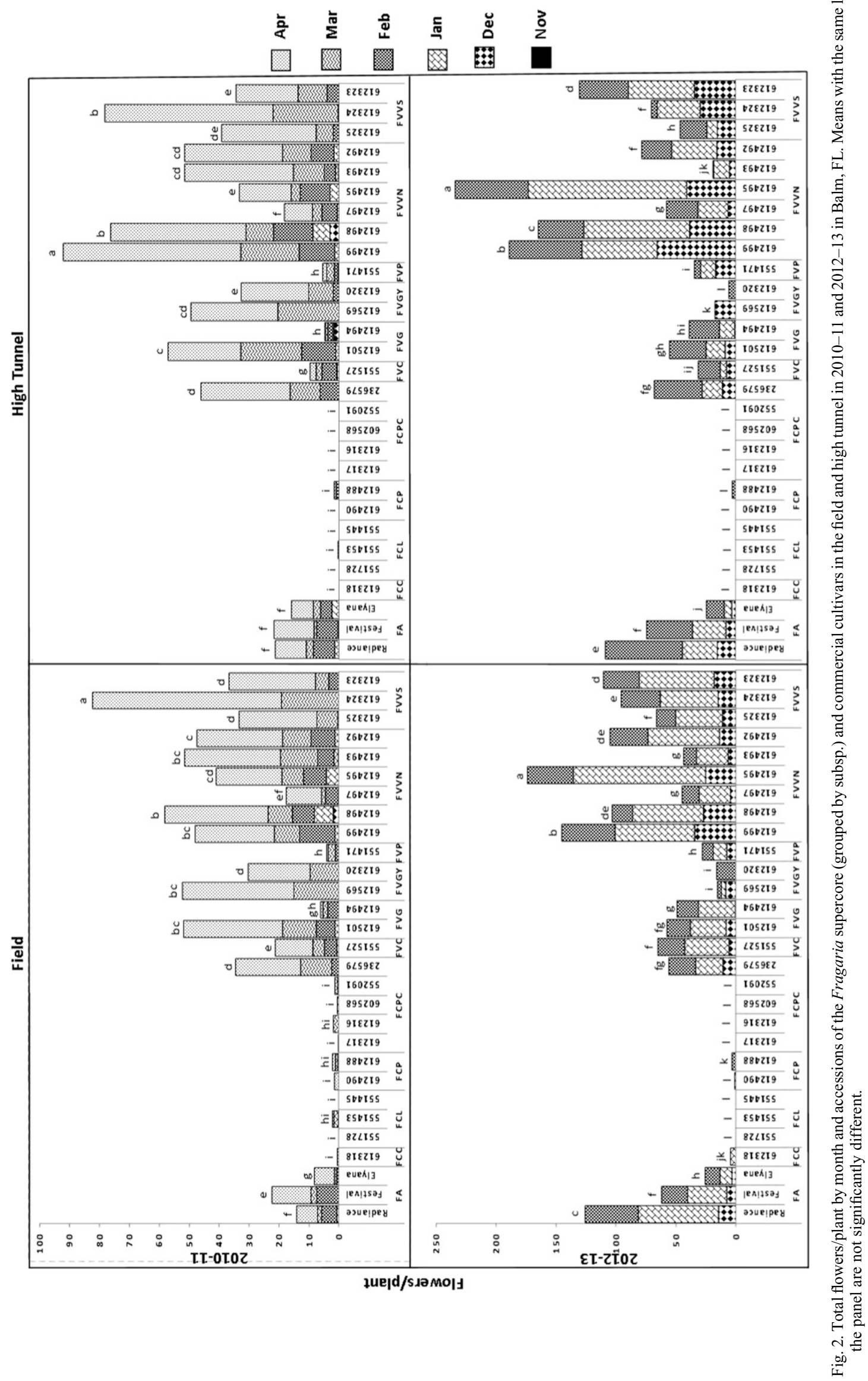




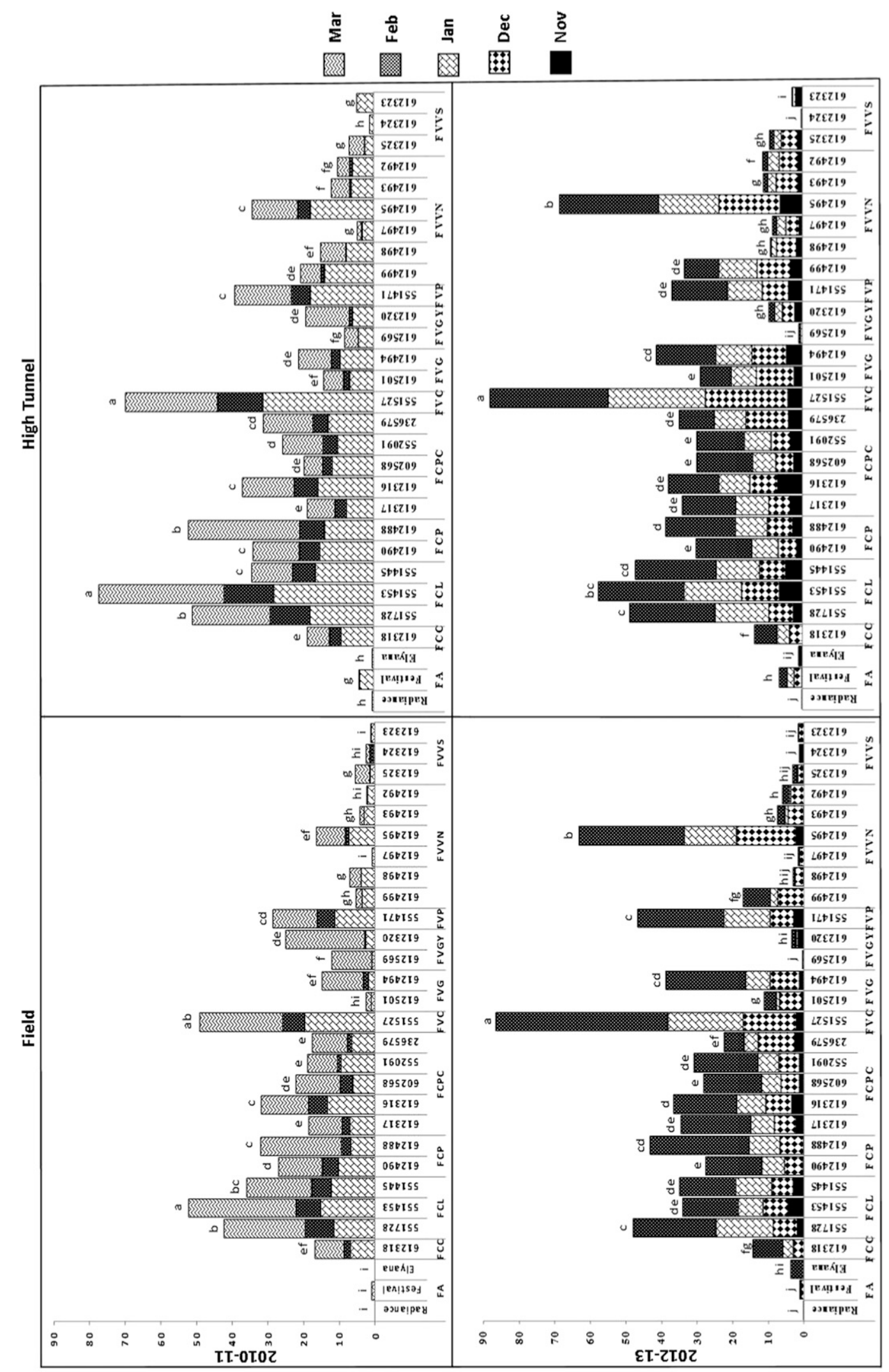

tue|d/s.sauny 
Table 6. Type III test of fixed effects of year, genotype, and environment on runner production of wild strawberry (Fragaria sp.) species accessions and commercial cultivars in Balm, FL, in 2010-11 and $2012-13$.

\begin{tabular}{lcrrr}
\hline Effect & Numerator df & Denominator df & F value & Pr $>$ F \\
\hline Environment (E) & 1 & 12 & 7.12 & 0.0205 \\
Genotype (G) & 28 & 336 & 124.18 & $<0.0001$ \\
G $\times$ E & 28 & 336 & 6.84 & $<0.0001$ \\
Year (Y) & 1 & 12 & 0.97 & 0.3441 \\
G $\times$ Y & 28 & 336 & 15.73 & $<0.0001$ \\
E $\times$ Y & 1 & 12 & 1.16 & 0.3033 \\
G $\times$ E $\times$ Y & 28 & 336 & 2.86 & $<0.0001$ \\
\hline
\end{tabular}

high tunnel in December; however, flowering in the field did not begin until January. There was more flowering in the early season in both environments in 2012-13 compared with 2010-11 that is likely the result of differences in seasonal temperatures (Fig. 1). During the first 6 weeks after planting, temperatures in 2010-11 were slightly higher compared with 2012-13. However, in December, temperatures in $2010-11$ were 10 to $12^{\circ} \mathrm{C}$ below those of 2012-13 and continued to remain below 2012-13 temperatures through February.

Accessions of the northern grouping of $F$. virginiana subsps. virginiana previously categorized as RM types from Minnesota and Montana (Table 1) flowered well in both years and environments; however, those accessions from Ontario, especially Montreal River 10 (PI 612497) and Fredrick 9 (PI 612493), had fewer flowers compared with other accessions within this grouping in both years and environments. Serçe and Hancock (2005) reported that Fredrick 9 had no difference in flower production under 8- and 16-h photoperiods at $18{ }^{\circ} \mathrm{C}$; however, under a 12-h photoperiod, Fredrick 9 did not flower at 22 or $26^{\circ} \mathrm{C}$. Because Montreal River 10 (PI 612497) and Fredrick 9 (PI 612493) had fewer flowers in the warmer year of 2012-13 compared with 2010-11, these accessions are likely susceptible to heat stress. Comparably, of the RM accession within $F$. virginiana subsps. glauca, Black Hills S. Dak (PI 612494) from South Dakota had less flowers than LH 30-4 (PI 612501) from Montana and had overall fewer flowers in the colder of the years (2010-11).

Runner production. For runner production, the triple interaction of year $x$ genotype $x$ environment was significant (Table 6); therefore, separate analyses are presented for year and environment (Fig. 3). Although the $F$. chiloensis accessions flowered poorly, they runnered prolifically. Albregts and Howard (1986) originally reported yield reductions related to retention of runners by the fruiting plant. Because these accessions flowered in a temperate environment (Hancock et al., 2001), it seems likely that the conditions for flowering were not met (most likely chill requirement) and these plants directed energy toward asexual reproduction instead. The $F$. chiloensis subsp. lucida had the highest number of runners/plant with an average of $43.5,53.8$, 38.9 , and 50.2 in the field and high tunnel in 2010-11 and 2012-13, respectively. Fragaria chiloensis subsp. $f$. chiloensis had the least average runners/plant with 16.8, 18.6, 14.3, and 13.3 in the field and high tunnel in 2010 11 and 2012-13, respectively. Among this group, NAH 3 (PI 612318) had the fewest runners, which corresponds with findings of Hancock et al. (2010). Among the group of F. chiloensisf. patagonica subsp. chiloensis, Rio Palena (PI 602568) had the fewest total runners/plant $(22.1,19.4,28.1$, and 29.3) in the field and high tunnel in 2010-11 and 2012-13, respectively.

The $F$. cascadensis accession had the overall highest number of runners/plant with 48.0, 69.2, 86.4, and 86.4 in the field and high tunnel in 2010-11 and 2012-13, respectively. On average, the $F$. virginiana accessions had the fewest number of runners/plant with $F$. virginiana subsp. virginiana (South) having the smallest average number ranging from 1.9 to 4.1 , which was similar to the commercial cultivars. Among the commercial cultivars, Radiance produced the fewest runners/plant ranging from 0.0 to 0.5 and Festival produced the most runners/plant ranging from 0.9 to 6.6. At the subspecies level, $F$. virginiana subsp. platypetala had the highest average number of runners/plant ranging from 28.5 to 46.6 .

In each year, total runner production was similar across environments for all accessions; however, there were differences between years for some subspecies and accessions. Both accessions within the $F$. virginiana subsp. grayana, NC 95-21-1 (PI 612569) and JP 959-6 (PI 612320), had more runners in 2010-11 compared with 2012-13. Although these genotypes originate from the deep south (Georgia and Mississippi), they may have suffered from a lack of vigor as a result of insufficient chilling in 2012-13 (Fig. 1). Among the group of $F$. virginiana subsp. virginiana (South) accessions, NC 96-48-1 (PI 612324) produced the fewest runners in both years and environments, whereas NC 96-5-3 (PI 612325) had the highest number of runners. Hancock et al. (2010) reported that NC 96-5-3 had the greatest percent bed fill when compared with other accessions in this group.

Within $F$. virginiana subsp. virginiana (North), LH 50-4 (PI 612495) produced the largest number of runners/plant with 16.3 and 33.9 in the field and high tunnel in 2010-11, respectively, and 63.0 and 67.2 in the field and high tunnel in 2012-13, respectively. This finding corresponds with those of Hancock et al. (2010) in which it was reported that within the $F$. virginiana subsp. virginiana (North) group, LH 50-4 had the greatest percentage of bed fill. Fredrick 9 (PI 612493) produced the least number of runners/plant with a range of 4.3 to 10.9 ; however, in Hancock et al. (2010), Montreal River 10 (PI 612497) had the smallest percentage of bed fill.

In 2012-13, runners/plant were approximately the same across environments, but in 2010-11, there were more runners/plant in the tunnel compared with the field. Although most accessions had more runners/plant in the high tunnel compared with the field, several including JP 95-9-6 (PI 612320), NC 95-21-1 (PI 612569), and NC 96-48-1 (PI 612324) from Georgia, Mississippi, and South Carolina, respectively, had fewer runners/plant in the high tunnel compared with the field in 2010-11. However, this exception did not occur in 2012-13. In 2012-13, BC Canada (PI 612488) from British Colombia and Ice H59 (PI 551471) from California had fewer runners/plant in the high tunnel compared with the field. Similar to flower production, there were generally more runners produced earlier in the season in the high tunnel in both years compared with the field.

\section{Conclusions}

With the exception of Darrow 72, $F$. chiloensis accessions did not perform well in the minimum-chill annualized winter and spring production system. The members of this species generally did not flower and, instead, were prolific in terms of runner production. The $F$. virginiana species exhibited better adaptation with $F$. virginiana subsps. grayana and virginiana appearing more adapted for minimum chill, winter production because these subsps. flowered well and had few runners. We conclude that SD accessions NC 96-48-1 (PI 612324) and NC 95-21-1 (PI 612569), and Darrow 72 (PI 236579) along with RM accession RH 30 (PI 612499 ) would be particularly attractive for inclusion in germplasm development. In addition to producing many flowers and few runners, they had low mortality and also were found to have resistance to powdery mildew in a companion study (Kennedy et al., 2013).

\section{Literature Cited}

Albregts, E.E. and C.M. Howard. 1986. Effect of runner removal on strawberry fruiting response. HortScience 21:97-98.

Barritt, B.H. and C.H. Shanks. 1980. Breeding strawberries for resistance to the aphids Chaetosiphon fragaefolii and Chaetosiphon thomasi. HortScience 15:287-288.

Bringhurst, R.S. 1976. Day-neutral vs. short-day strawberry breeding advantages and exploitation potential. Fruit Var. J. 30:25.

Bringhurst, R.S. and V. Voth. 1984. Breeding octoploid strawberries. Iowa State J. Res. 58:371-381

Dale, A., J.J. Luby, and J.F. Hancock. 2002. Breeding dayneutral strawberries for northern North America. Acta Hort. 567:133-136.

Daubeny, H.A. 1990. Strawberry breeding in Canada. HortScience 25:893-894.

Donoso, T.P.S., B.M. Santos, C. Chandler, and S. Sargent. 2009. Effects of high tunnel production on Florida strawberry cultivars. HortScience 44:1051. 
Durner, E.F., E.B. Poling, and E.A. Albregts. 1987. Early season yield responses of selected strawberry cultivars to photoperiod and chilling in a Florida winter production system. J. Amer. Soc. Hort. Sci. 112:53-56.

Finn, C.E., J.B. Retamales, G.A. Lobos, and J.F Hancock. 2013. The Chilean strawberry (Fragaria chiloensis): Over 1000 years of domestication. HortScience 48:418-421.

Florida Automated Weather Network. 2014 Report generator. FAWN, University of Florida, Gainesville, FL. 24 Mar. 2014. <http://fawn.ifas. ufl.edu/data/reports/>.

Galletta, G.J., A.D. Draper, and J.L. Maas. 1989. Combining disease resistance, plant adaptation and fruit quality in breeding short day and dayneutral strawberries. Acta Hort. 265:43-51.

Hancock, J. and D. Simpson. 1995. Methods of extending the strawberry season in Europe. HortTechnology 5:286-290.

Hancock, J.F. 1999. Strawberries. CABI Publishing, New York, NY.

Hancock, J.F., C.A. Finn, S.C. Hokanson, J.J Luby, B.L. Goulart, K. Demchak, P.W. Callow, S. Serçe, A.M.C. Schilder, and K.E. Hummer. 2001. A multistate comparison of native octoploid strawberries from North and South America. J. Amer. Soc. Hort. Sci. 126:579-586.

Hancock, J.F., C.E. Finn, J.J. Luby, A. Dale, P.W. Callow, and S. Serçe. 2010. Reconstruction of the strawberry, Fragaria $\times$ ananassa, using genotypes of $F$. virginiana and $F$. chiloensis. HortScience 45:1006-1013.

Hancock, J.F., S.C. Hokanson, C.E. Finn, and K.E. Hummer. 2002. Introducing a supercore collection of wild octoploid strawberries. Acta Hort. 567:77-79.
Heide, O.M., J.A. Stavang, and A. Sonsteby. 2013. Physiology and genetics of flowering in cultivated and wild strawberries - A review. J. Hort. Sci. Biotechnol. 88:1-18.

Hummer, K.E. 2012. A new species of Fragaria (Rosacea) from Oregon. J. Bot. Res. Inst. Texas 6:9-15.

Kennedy, C., T.N. Hasing, N.A. Peres, and V.M Whitaker. 2013. Evaluation of strawberry species and cultivars for powdery mildew resistance in open-field and high tunnel production systems. HortScience 48:1125-1129.

Luby, J.J., J.F. Hancock, A. Dale, and S. Serçe. 2008. Reconstructing Fragaria $\times$ ananassa utilizing wild $F$. virginiana and $F$. chiloensis: Inheritance of winter injury, photoperiod sensitivity, fruit size, female fertility and disease resistance in hybrid progenies. Euphytica 163:57-65.

Ludwig, A., K. Olbricht, M. Bartho, P. Scheewe, S. Plaschil, and M. Boehme. 2013. Evaluation of Canadian accessions of Fragaria virginiana Miller with regard to strawberry breeding. Acta Hort. 976:221-225.

Ogden, A.B. and M.W. van Iersel. 2009. Southern highbush blueberry production in high tunnels: Temperatures, development, yield, and fruit quality during the establishment years. HortScience 44:1850-1856.

Pinkerton, J. and C.E. Finn. 2005. Responses of strawberry species and cultivars to the rootlesion and northern root-knot nematodes. HortScience 40:33-38.

Salame-Donoso, T.P., B.M. Santos, C.K. Chandler, and S.A. Sargent. 2010. Effects of high tunnels on strawberry growth, yield, and postharvest quality in Florida. HortScience 45:503.
Santos, B.M., N.A. Peres, J.F. Price, V.M. Whitaker, P.J. Dittmar, S.M. Olson, and S.A. Smith. 2011. Strawberry production in Florida UF/IFAS, Gainesville, FL 24 Mar. 2014. <http:// edis.ifas.ufl.edu/cv134>

Serçe, S. and J.F. Hancock. 2005. The temperature and photoperiod regulation of flowering and runnering in the strawberries, Fragaria chiloensis, $F$. virginiana, and $F . \times$ ananassa. Sci. Hort. 103:167-177.

Stegmeir, T.L., C.E. Finn, R.M. Warner, and J.F. Hancock. 2010. Performance of an elite strawberry population derived from wild germplasm of Fragaria chiloensis and $F$. virginiana. HortScience 45:1140-1145.

Stewart, P.J. 2011. Strawberry Part 1: Fragaria history and breeding, p. 114. In: Folta, K.M and C. Kole (eds.). Genetics, genomics and breeding of berries. Science Publishers, Enfield, NH.

Stewart, P.J. and K.M. Folta. 2010. A review of photoperiodic flowering research in strawberry (Fragaria spp.). Crit. Rev. Plant Sci. 29:1-13.

Summerfield, R.J. 1999. Timing it right: The measurement and prediction of flowering. Acta Agronomica Hungarica 47:203-213.

USDA, ARS, National Genetic Resources Program. 2014. Germplasm Resources Information Network (GRIN) [online database]. USDA, ARS, National Germplasm Resources Laboratory, Beltsville, MD. 24 Mar. 2014. <http://www. ars-grin.gov/cgi-bin/npgs/html/index.pl>.

USDA, NRCS, National Soil Survey Center. 2013. Web soil survey. USDA, Lincoln, NE. 24 Mar. 2014. <http://websoilsurvey.nrcs.usda. gov/app/>. 